\title{
Tyrosine kinase inhibitors target cancer stem cells in renal cell cancer
}

\author{
ANNA M. CZARNECKA, WOJCIECH SOLAREK, ANNA KORNAKIEWICZ and CEZARY SZCZYLIK \\ Laboratory of Molecular Oncology, Department of Oncology, Military Institute of Medicine, 04-141 Warsaw, Poland
}

Received September 20, 2015; Accepted October 31, 2015

DOI: $10.3892 /$ or.2015.4514

\begin{abstract}
This study was designed to analyze the impact of multi-targeted tyrosine kinase inhibitors on the cancer stem cell subpopulation in renal cell cancer. The second objective was to evaluate the effect of tumor growth inhibition related to a tumor niche factor - oxygen deprivation - as hypoxia develops along with the anti-angiogenic activity of tyrosine kinase inhibitors in renal tumors. Cells were treated with tyrosine kinase inhibitors, sunitinib, sorafenib and axitinib, in 2D and 3D culture conditions. Cell proliferation along with drug toxicity were evaluated. It was shown that the proliferation rate of cancer stem cells was decreased by the tyrosine kinase inhibitors. The efficacy of the growth inhibition was limited by hypoxic conditions and 3D intratumoral cell-cell interactions. We conclude that understanding the complex molecular interaction feedback loops between differentiated cancer cells, cancer stem cells and the tumor microenvironment in 3D culture should aid the identification of novel treatment targets and to evalute the efficacy of renal cancer therapies. Cell-cell interaction may represent a critical microenvironmental factor regulating cancer stem cell self-renewal potential, enhancing the stem cell phenotype and limiting drug toxicity. At the same time the role of hypoxia in renal cancer stem cell biology is also significant.
\end{abstract}

\section{Introduction}

The clinical and biological anticancer effects produced by tyrosine kinase inhibitors (TKIs) in renal cell cancer (RCC) are the result of their inhibitory activities on a variety of cell receptors on cancer cells, endothelial cells, pericytes, and stromal cells (1). The targeted effects of TKIs are dependent on the inhibition of downstream mediators upregulated in response to molecular abnormalities (i.e., VHL, c-MET) in

Correspondence to: Dr Anna M. Czarnecka, Laboratory of Molecular Oncology, Department of Oncology, Military Institute of Medicine, Szaserow 128, 04-141 Warsaw, Poland

E-mail: anna.czarnecka@gmail.com

Key words: renal cell cancer, cancer stem cells, tyrosine kinase inhibitors, sunitinib, axitinib
RCC. Specifically, in clear cell renal cell cancer (ccRCC), the mutations and/or epigenetic silencing of the VHL gene promote subsequent overexpression of growth factors, including the vascular endothelial growth factor receptor (VEGFR) and platelet-derived growth factor (PDGF), and multiple other hypoxia-regulated genes (EPO, NOS, GLUT-1, CA IX), all of which are co-responsible for tumor angiogenesis and cell proliferation (2,3). A group of targeted agents selective against RCC has been developed and introduced in the clinic over the last decade $(4,5)$. More recently, cancer stem cells (CSCs) or tumor-initiating cells have come into focus as potential treatment targets in solid tumors $(6,7)$ and RCCs $(8,9)$.

Sunitinib (SU11248) is a multi-targeted kinase inhibitor of VEGFR-1, -2 and -3, PDGFR- $\beta$, mast/stem cell growth factor receptors (SCFR, c-Kit) and FMS-like tyrosine kinase 3 (FLT3) (10). Sunitinib inhibits cancer growth primarily through an anti-angiogenic mechanism, by halting endothelial cell proliferation and motility (11). The elucidated mechanisms of action of sunitinib may also include targeting CSCs. The first study to show that sunitinib targets CSCs was conducted in pancreatic cancer. In this study, $\mathrm{CD} 24^{+} \mathrm{CD} 44^{+} \mathrm{ESA}{ }^{+}$triplepositive pancreatic CSCs were shown to be responsive to this TKI in combination with liposome-coated doxorubicin (12). In prostate cancer, in a PC3 cell-based model, sunitinib was shown to reduce the number of $\mathrm{ALDH}^{+}$cancer stem-like cells, and to sensitize these cells to the radiation-mediated loss of clonogenicity (13). In xenograft RCC models, sunitinib has been shown to generate resistance to its own therapeutic mechanism due to the induction of hypoxia in perinecrotic areas. Moreover, CD133/CXCR4 co-expressing cells, also considered CSCs, were found in these areas at higher numbers. Under hypoxia, the tumorigenic potential of CD133/CXCR4 ${ }^{+}$cells increased, and their sensitivity to sunitinib decreased (14).

Sorafenib (BAY 43-9006) was discovered based on its ability to inhibit kinases, including C-RAF and B-RAF (wild-type and V600E mutant), and subsequent MEK and ERK phosphorylation. It also targets VEGFR-2 and VEGFR-3, PDGFR- $\beta$, FLT3, and c-Kit (15). The complete mechanisms of action include a reduction in angiogenesis and cancer cell proliferation. However, the exact mechanisms remain undefined. In the case of hepatocellular carcinoma (HCC), it was demonstrated that label-retaining cancer cells (LRCCs), a subpopulation ofCSCs, were significantly resistant to sorafenib. In addition, the proportion of LRCCs in the HCC cell lines was increased in the total culture after sorafenib treatment (16). 
Moreover, CD44/CD133 ${ }^{+}$and CD44/ALDH1A1 ${ }^{+} \mathrm{HCC}$ cells (CSCs) were shown to increase in number after treatment with sorafenib $(17,18)$. After treatment with sorafenib, starting at a concentration of $1 \mu \mathrm{M}$ and increased by $10 \%$ every 2 weeks until reaching the maximum tolerated dose $(4-7 \mu \mathrm{M})$, the number of $\mathrm{CD} 44 / \mathrm{CD} 133^{+}$stem cells increased in the HCC cell lines (17). However, another HCC subpopulation, $\mathrm{CD}^{+} 3^{+} /$ $\mathrm{CD} 166^{+} / \mathrm{ALDH}^{+} \mathrm{CSCs}$, was determined to be sensitive to sorafenib (19). On the contrary, HCC CSC-defined by the expression of the Nanog gene also exhibited resistance to sorafenib (20).

It was later determined that it is the combination of two drugs that enables sorafenib to target the HCC CSCs. Sorafenib, in combination with FH535 (an inhibitor of Wnt//catenin signaling and dual antagonist of PPAR $\gamma / \delta$ activity), inhibited the proliferation of liver CSCs (CD133, CD44, CD24, and aldehyde dehydrogenase 1-positive) (21). A similar effect was noted for the combination of sorafenib and gedatolisib (PKI-587), a highly potent dual inhibitor of $\mathrm{PI} 3 \mathrm{~K} \alpha, \mathrm{PI} 3 \mathrm{~K} \gamma$ and mTOR (22). Sorafenib was also shown to effectively target pancreatic CSCs $\left(\mathrm{CD} 24^{-/ \mathrm{CD}} 44^{+}\right.$and $\left.\mathrm{ALDH}^{+}\right)$when administered with sulforaphane, a phytochemical belonging to the family of isothiocyanates (23). In the case of breast cancer, sorafenib has been shown to be effective against breast cancer $\mathrm{CD} 44^{+} \mathrm{CD} 24^{-}$stem cells in combination with radiation (24). Contrary to its low activity in HCC, sorafenib was shown to be effective in vitro against CSCs in glioblastomas (tumorinitiating cells) in primary cell cultures by inhibiting the PI3K/ Akt and MAPK pathways. In this case, sorafenib significantly induced apoptosis by downregulating the survival factor myeloid cell leukemia 1 (Mcl-1) (25), which was further potentiated by metformin (26). The combination of metformin and sorafenib was also shown to be significantly toxic to radioiodine refractory anaplastic thyroid carcinoma CSCs (27). In addition, it was shown to be effective against prostate cancer stem-like cells isolated from holoclones of the PC 3 cell line (28). Finally, RCC CXCR4 ${ }^{+}$cells, which express stem cell-associated transcription factors (NANOG,OCT3/4, and $S O X 2)$ at elevated levels, were reported to be more resistant to sorafenib (and sunitinib) than the parental cells in adherent cultures (9).

Axitinib (AG-013736) is a potent small-molecule inhibitor of multiple tyrosine kinases, including VEGFR-1, -2 and -3 and PDGFR $\beta$. Therefore, axitinib inhibits endothelial cell survival, new tube formation, and nitric oxide (NO), protein kinase $\mathrm{B}$ (PKB, Akt), and extracellular signal-regulated kinase (ERK) signaling in endothelial cells (29). It was shown that AG-013736 alone, or in combination with radiotherapy treatment, induces functional normalization of the tumor vasculature (30). In glioblastomas, in an S1-M1-80 cell line xenograft model, axitinib was shown to target a side population (SP), referred to by the authors as cancer stem-like cells. It was shown to inhibit the transporter activity of the adenosine triphosphate (ATP)-binding cassette subfamily G member 2 (ABCG2), reversing ABCG2-mediated drug resistance. In this model, axitinib (every 4 days $x$ 9, p.o., $25 \mathrm{mg} / \mathrm{kg}$ ) enhanced the cytotoxicity of topotecan and mitoxantrone against an SP (31). Subsequently, it was also shown that axitinib exerts direct cytotoxic activity against patient-derived glioblastoma CSCs (32) and potentiates myxoma virus-based treatment directed against brain tumor-initiating cells (33). In another study based on the PC3 cell line, holoclone-derived cancer stem-like cells (called PC $3 / 2 \mathrm{G} 7$ ) in a prostate cancer model were shown to be sensitive to axitinib (28). Later, it was shown that $1 \mu \mathrm{M}$ axitinib in vitro increased the toxic effects of non-small cell lung cancer (NSCLC) cell irradiation respectability when applied to spheres derived from CD24/CD44+ NSCLC CSCs (34).

In terms of the tumor microenvironment-dependent activity of TKIs, it was first suggested that sunitinib (and possibly other VEGF inhibitory compounds) increased the population of CSCs in the tumor by generating intratumoral hypoxia. Xenograft-based breast cancer studies revealed that hypoxia-driven cancer stem or progenitor cell enrichment resulted from hypoxia-inducible factor $1 \alpha(\mathrm{HIF} 1 \alpha)$ signaling. Therefore, it was concluded that an increase in the number of hypoxia-driven CSCs limits the effectiveness of antiangiogenic agents as a result of CSC drug resistance (35). It was multitargeted VEGFR inhibition (with sunitinib), not VEGF sequestration (with bevacizumab), that rapidly created a vascular gradient, inducing tumor hypoxia, promoting the aggressive mesenchymal phenotype, and increasing the cancer stem cell number (36). In a mouse based study, oral sunitinib administered at $80 \mathrm{mg} / \mathrm{kg} / 2$ days for 4 weeks significantly reduced the tumor volume and angiogenesis, but increased the number of CSCs in the tumors (37). We hypothesized that TKIs suppress tumor angiogenesis and tumor growth and progression via inhibition of the paracrine and autocrine effects of VEGF; however, TKI-induced tumor hypoxia may promote the CSC phenotype. Since the data on TKI activity against renal cell CSCs is not available, we aimed to verify whether renal CSCs are targeted by TKIs in an RCC model. We aimed to verify the influence under both normoxic and hypoxic conditions, which would represent conditions prior to and post-TKI exposure.

\section{Materials and methods}

Renal cell cancer-cancer stem cell isolation. Individual donor samples were selected for the study, and selected donations were used for analysis. Primary tumor tissue was obtained. The tumor samples obtained after surgery were placed immediately in tumor transportation media and shipped at $4-8^{\circ} \mathrm{C}$ for processing. Tissues were washed with $1 \mathrm{X}$ PBS solution, divided into two halves and aseptically cut into $0.5-\mathrm{mm}$ sections and cultured in 6-well tissue culture plates precoated with extracellular matrix. First, the control half was processed in regular media with serum and was referred to as the parental cell line, while CSCs were selected in Kidney Cancer Stem Cell Complete Growth Medium (Celprogen, San Pedro, CA, USA) $(38,39)$. All cell cultures remained viable and maintained their native architecture for at least 14 days. After 14 days of culture, the cells were characterized for stem cell phenotype.

As previously described, cancer, kidney cancer and CSC surface markers, transcription factors and epithelial-mesenchymal transition (EMT) markers (linked to the induction of a stem-cell like phenotype) were quantified by qPCR or immunocytochemistry per cell culture. These markers included: human kidney injury molecule-1 (hK1M1), renal cell carcinoma marker (RCC-Ma), chromophobe 
renal cell carcinoma (chRCC), calveolin-1 (CAV-1), carbonic anhydrase IX (CA9/CAIX), vascular endothelial growth factor (VEGF), chemokine (C-X-C motif) ligand 16 (CXCL16), A disintegrin and metalloproteinase domain-containing protein 10 (ADAM10, CD156c), programmed death-ligand 1 (PD-L1; also known as cluster of differentiation 274, CD274 or B7 homolog 1, B7-H1), Ki-67, survivin, P53, glucose transporter 1 (GLUT-1), galctosyl transferase II (GalT-II), glyceraldehyde 3-phosphate dehydrogenase (GAPDH), cancer antigen 19 (CA19-9), cancer antigen 72-4 (CA72-4), carcinoembryonic antigen (CEA), $\alpha$-fetoprotein (AFP), $\beta$-2-microglobulin (B2M), octamer-binding transcription factor 4 (OCT4), sexdetermining region Y-box 2 (SOX-2), stage-specific embryonic antigen-3 and -4 (SSEA3/4), aldehyde dehydrogenase (ALDH), alkaline phosphatase (ALP), tissue-non-specific alkaline phosphatase (TRA1-81 and TRA1-61), telomerase, CD9, CD10, CD24, CD34, CD40, CD44, CD105 (endoglin), CD133 (prominin-1), CXCR-4, SHH (sonic hedgehog), epithelial cell adhesion molecule (EpCAM), epithelial-specific antigen (ESA), CBX7, SNAIL, SLUG, TWIST, Ki-67, E-cadherin, $\beta$-catenin, nestin and vimentin $(38,40,41)$.

SCID nude mice were subcutaneously injected with 1,000 CSCs in the hind limbs. Subcutaneous tumors developed. Cells were capable of generating tumors in mice within 20 days. The mice were also evaluated for metastases. Cells tumorigenic at the above mentioned injection concentration were selected for further experiments. Stem cell marker expression was re-confirmed in the developed tumors $(38,41,42)$.

Cells positive for Sox 2, Oct4, SSEA3/4, ALDH, ALP, telomerase, calveolin-1, CD133 and CD44, that were also capable of clonal self-renewal and were tumorigenic with $<1,000$ cells injected as described above, were used for further investigation. Cells were characterized and stable for markers for up to seven passages. Markers were significantly expressed at a higher level compared with the expression levels in normal kidney tissues and primary renal cancer cells $(38,40,41)$.

Cell culture. Human kidney cancer stem cells (HKCSCs, RCC-CSCs; Celprogen, Torrance, CA, USA) were cultured in Human Kidney Cancer Stem Cell media as per the manufacturer's protocol requirements. 786-0 (CRL-1932), a primary tumor-derived VHL mutated cell line, was obtained from the American Type Culture Collection (ATCC) Global Bioresource Center (Manassas, VA, USA). The SK-RT-42 metastatic bone-derived cell line was established in the laboratory of Dr Lloyd Old, from patients undergoing nephrectomy at Memorial Hospital, Memorial Sloan Kettering Cancer Center (MSKCC) and was obtained from the Core Facility, MSKCC (New York, NY, USA) (43). The 786-0 and SK-RT-42 cell lines were cultured in RPMI-1640 medium with 10\% FBS (Biochrom GmbH, Cambridge, UK) and GlutaMAX (Life Technologies, Carlsbad, CA, USA). RCC-CSCs were differentiated with RPMI-FBS under culture conditions described above. Cells were cultured under normoxic $\left(21 \% \mathrm{O}_{2}\right)$ and hypoxic $\left(1 \% \mathrm{O}_{2}\right)$ conditions. Human Kidney Cancer Stem Cell Extracellular Matrix was used to increase RCC-CSC viability (Celprogen).

$3 D$ cell culture. In the $3 \mathrm{D}$ approach, CSCs were grown in media as above but as aggregates and in hanging drop culture forming spheroids as previously described $(44,45)$, with modification of 100 cells $/ 10 \mu 1$ drop. After formation of the spheroids ( $72 \mathrm{~h}$ ), sunitinib was added in a volume of $5 \mu \mathrm{l}$ to each drop in order to obtain $0,1,2,4,8$, and $15 \mu \mathrm{M}$ concentrations. Spheres were photographed under a Nikon TMS-F phase contrast microscope after 24,48 and $72 \mathrm{~h}$. The size of the colonies was analyzed using ImageJ software as previously published $(46,47)$.

Assessment of drug toxicity. The cells were treated with TKIs, sunitinib malate, axitinib (Sigma-Aldrich, St. Louis, MO, USA) or sorafenib (Cayman Chemical Co., Ann Arbor, MI, USA) at different concentrations (0, 1, 2, 4, 6, 8, 10, 12, 15 and $20 \mu \mathrm{M}$ ) with DMSO $<0.5 \%$ (control). Subsequently $\mathrm{IC}_{50}$ values of the TKIs were evaluated after 24,48 and $72 \mathrm{~h}$. The cells were also treated with TKIs under normoxic $\left(21 \% \mathrm{O}_{2}\right)$ or hypoxic $\left(1 \% \mathrm{O}_{2}\right)$ conditions. HKCSCs were seeded in 96-well 2D plates and cultured under standard conditions $\left(37^{\circ} \mathrm{C}, 5 \%\right.$ $\mathrm{CO}_{2}$ ). After $24 \mathrm{~h}$, sunitinib was added and the plates were moved to a normoxic or hypoxic incubator. Subsequently, inhibition of proliferation was quantified after 24, 48 and $72 \mathrm{~h}$. Alamar blue (resazurin) (Life Technologies) assay was performed as per the manufacturer's protocol to quantitatively measure cell viability and cytotoxicity (48) which were read by microplate reader Multiskan GO and analyzed using ScanIt ${ }^{\mathrm{TM}}$ software package (Thermo Scientific, Waltham, MA USA). MTT [3-(4,5-dimethylthiazol-2-yl)-2,5-diphenyltetrazolium bromide] assay (Life Technologies) was used to assess cell viability under TKI treatment as previously published $(49,50)$.

\section{Results}

Tyrosine kinase inhibitors target renal cell cancer-cancer stem cells. RCC-CSCs were found to be slow proliferators in comparison to stable (differentiated) renal cell cancer cells, and all TKIs (sunitinib, sorafenib, axitinib) were found to directly influence RCC-CSCs. Under TKI treatment, the proliferation rate of the RCC-CSCs was decreased (Figs. 1 and 2). The inhibition of proliferation was dose-dependent, with a significant RCC-CSC toxic minimal dose of $2 \mu \mathrm{M}$ TKI (Fig. 1); however, this inhibition was evident after $22 \mathrm{~h}$ of drug treatment at high sunitinib doses $(>6 \mu \mathrm{M})$ (Fig. 1A), and also significant at a low dose $(2 \mu \mathrm{M})$ (Fig. 1B) after $72 \mathrm{~h}$ of culture. The metabolic activity of the cells (seeded at least at $1 \times 10^{4}$ cells $/ \mathrm{ml}$ ) growing under TKIs appeared to slow down by day 3, suggesting that the surfaces were advancing toward confluency. At a lower seeding number (starting at 500/well), the cell culture was extended for 6 days of treatment in order to prolong the observation of the exponential/linear growth phase, focusing on the effect of TKIs on the cells at their point of maximum growth (Figs. 1B and 3). The inhibition of the proliferation by sunitinib was shown to be dose-dependent (Figs. 1 and 3A), and it was determined (for RCC-CSCs) that the half-maximal inhibitory concentration $\left(\mathrm{IC}_{50}\right)$ for sunitinib was at the 10 $\mu \mathrm{M}$ level (Fig. 2). The activity of axitinib against RCC-CSCs was lower than that for sunitinib. In regards to the regular ccRCC 786-0 cell line, the inhibition of cell proliferation was significant on day 6 of the axitinib treatment, while the cell growth of the RCC-CSCs was not inhibited using the same concentration of the drug (Figs. $3 \mathrm{C}$ vs. E and 4). A similar 
A

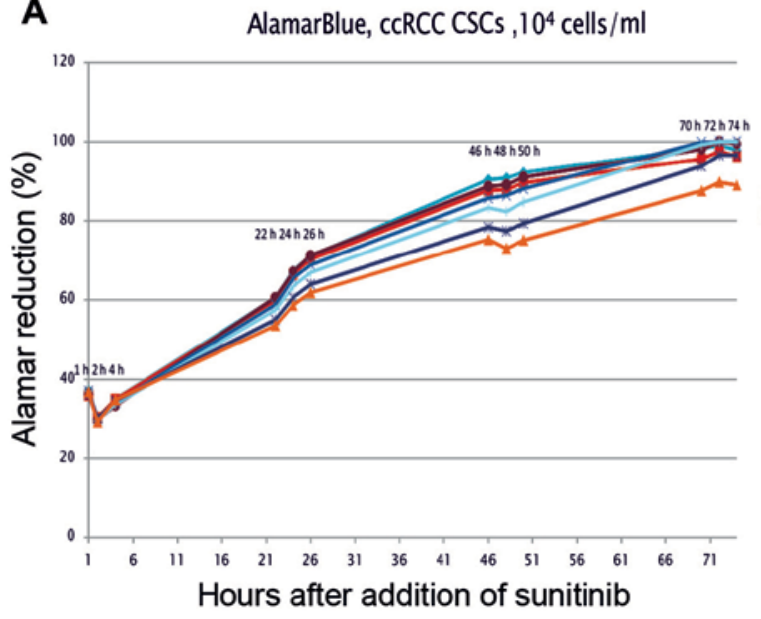

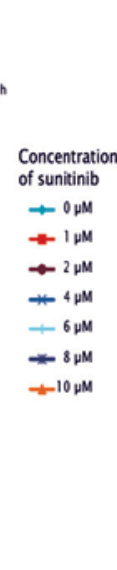

B

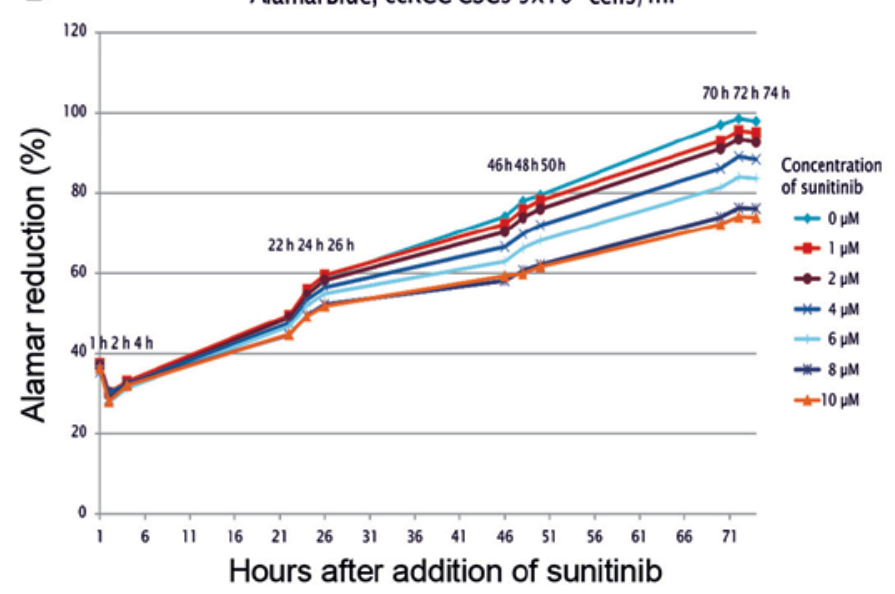

Figure 1. Sunitinib induces renal cell cancer-cancer stem cell (ccRCC-CSC) toxicity at a higher (A) and lower (B) cell seeding density.

A

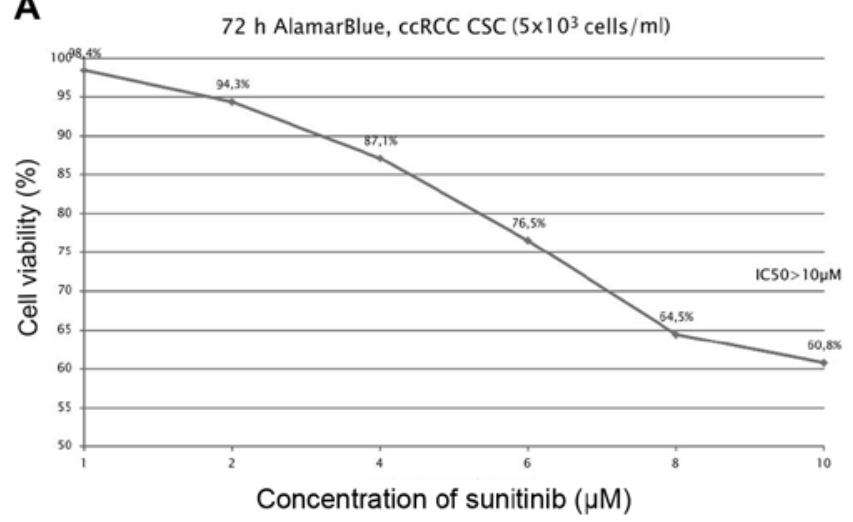

B

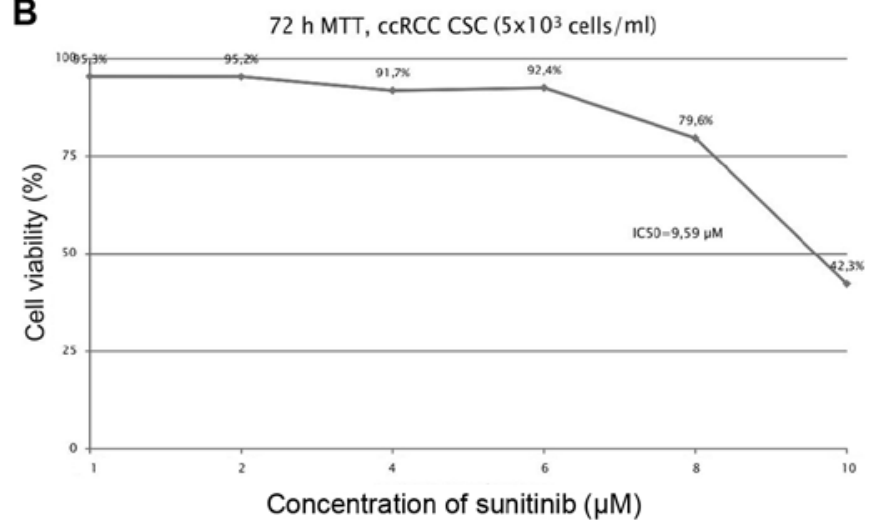

Figure 2. The half maximal inhibitory concentration $\left(\mathrm{IC}_{50}\right)$ of sunitinib against renal cell cancer-cancer stem cells (ccRCC-CSCs) as determined using AlmarBlue (A) and MTT (B) methods.

trend was confirmed for the SK-RC-42 metastatic cell line (data not shown).

Anti-proliferative activity of tyrosine kinase inhibitors is altered by hypoxia. The proliferation of renal cell cancer cells representing differentiated cancer cells (786- 0 cells and postRCC-CSCs), as well as RCC-CSCs/HKCSCs are influenced by oxygen tension in the environment. Normoxic $\left(21 \% \mathrm{O}_{2}\right)$ conditions promoted the growth of the renal cancer cell lines 786-O and SM-KT-42 under no-TKI treatment (Fig. 5). Moreover, when differentiated by the overload of growth factors (FBS), RCC-CSCs also proliferated at a significantly higher rate under high oxygen availability. Differentiated postRCC-CSCs showed a high proliferation rate, similar to that of the 786-0 cell line, and significantly higher than in RCC-CSCs in stem cell promoting conditions (Fig. 6). At the same time, RCC-CSCs under hypoxia changed their morphology and developed less invadopodia (Fig. 7D) (51), which is also typical when RCC-CSCs are cultured in ECM-rich conditions (Fig. 7A). Under a hypoxic condition, the activity of sunitinib (Fig. 8) and other TKIs was limited with the highest activity of sorafenib (Fig. 4B), and the influence of low oxygen tension was visible after $72 \mathrm{~h}$ in a hypoxic culture. During the first $24 \mathrm{~h}$, cells in normoxia and hypoxia proliferate at similar rates, but the reduction in sunitinib toxicity and concurrent induction of RCC-CSC proliferation under hypoxia were time-dependent (48 h; data not shown), which increased with time at low cell seeding and were visible after 6 days of culture (Fig. 3B).

The anti-proliferative activity of sunitinib decreased under a hypoxic condition, which may occur due to tumor cell-cell interactions between cancer cells, and has been investigated in tumorispheres. Additionally, the anti-proliferative activity of sunitinib also decreased in the 3D environment, which further increased the hypoxic condition, likely to occur in tumors (Fig. 9). The size of the spheres that developed in hypoxia under sunitinib treatment was larger than those developing during normoxia (Fig. 10), which further confirms the pro-proliferatory effect of hypoxia on RCC-CSCs.

\section{Discussion}

Recent achievements in the development of multi-targeted molecular inhibitors has necessitated a better understanding of the activity against individual targets with regard to their efficacy. Sunitinib, sorafenib, and axitinib are the most recently 
A
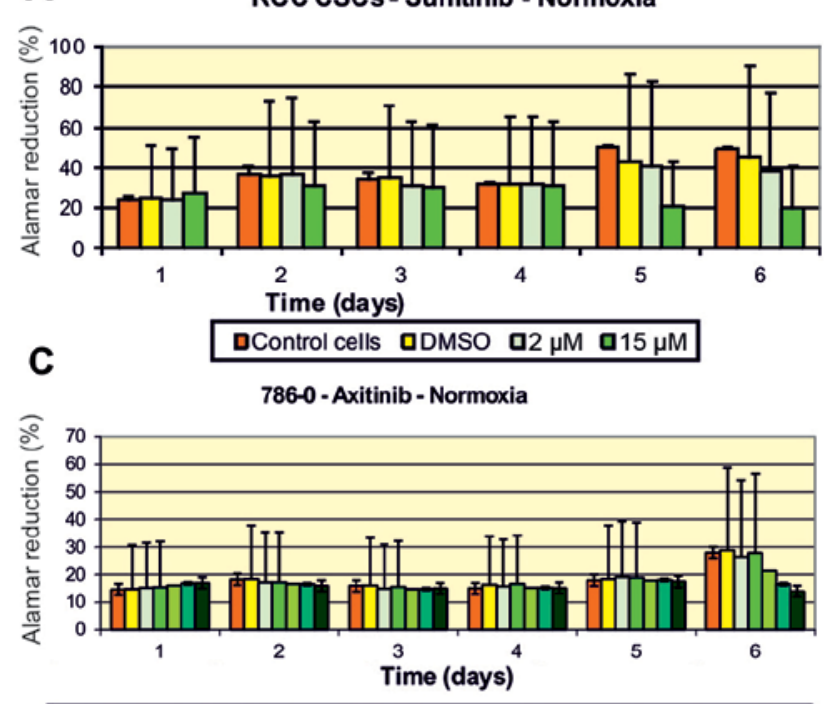

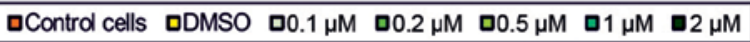

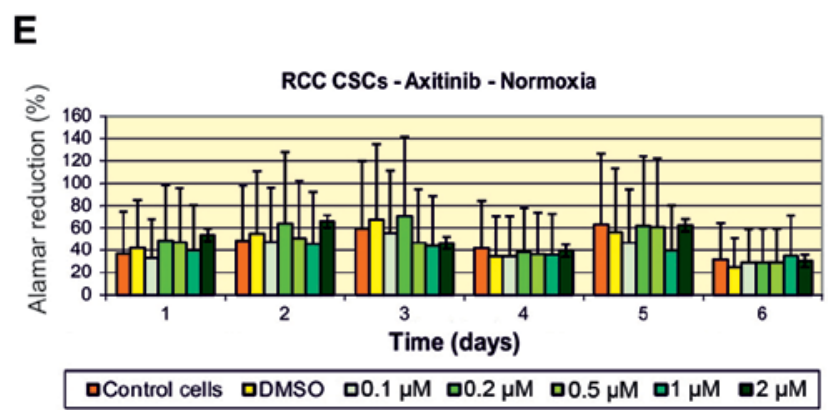

B

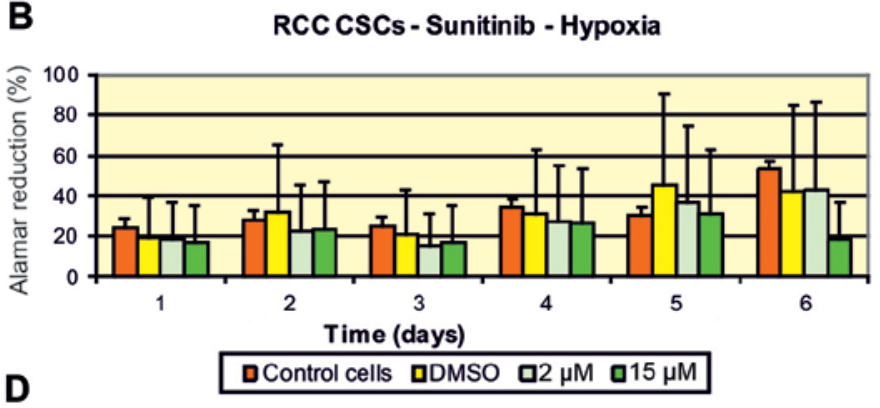

786-0 -Axitinib - Hypoxia

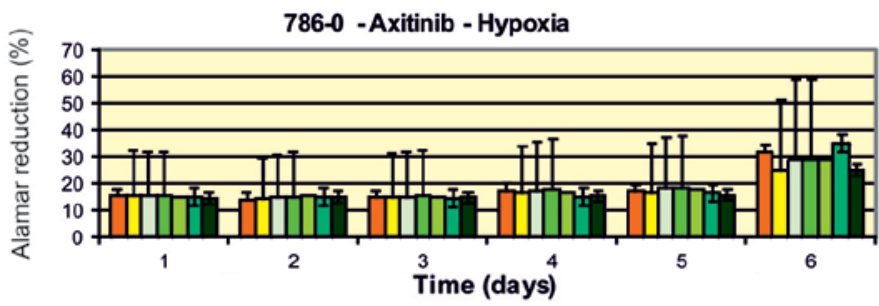

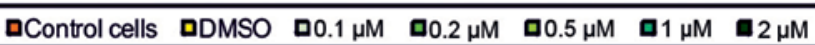

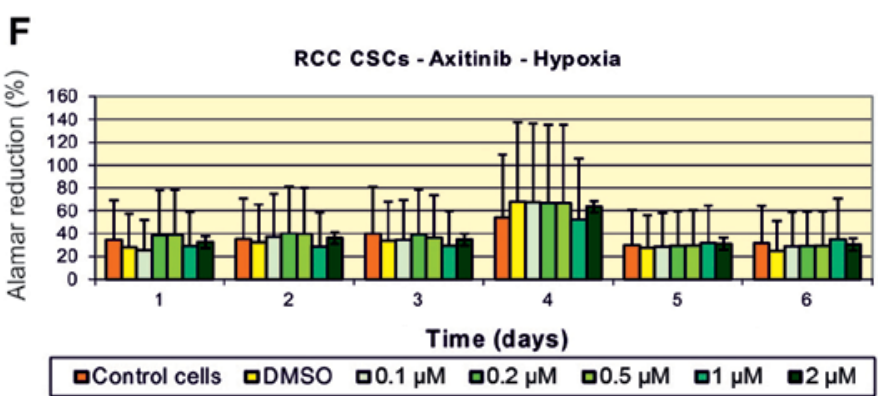

Figure 3. Sunitinib (A and B) and axitinib (C-F) induce a toxic effect on renal cell cancer 786-0 cells (C and D) and renal cell cancer-cancer stem cells (RCCCSCs) (A, B, E and F) under hypoxia (B, D and F) and normoxia (A, C and E).

A

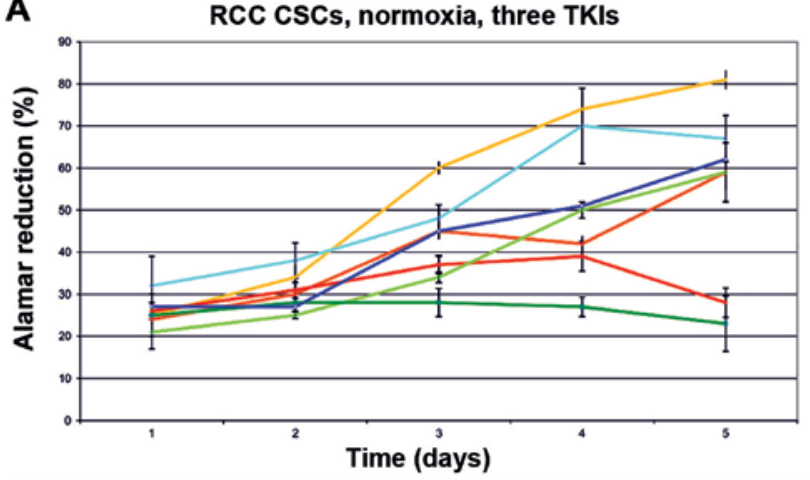

Colls $-0.5 \mu \mathrm{M}$ sunitinib $-2 \mu \mathrm{M}$ sunitinib $-0.5 \mu \mathrm{M}$ Sorafonib $\rightarrow 2 \mu \mathrm{M}$ Sorafonib $\rightarrow 0.5 \mu \mathrm{M}$ Axitinitb $--2 \mu \mathrm{M}$ Axitinit
B

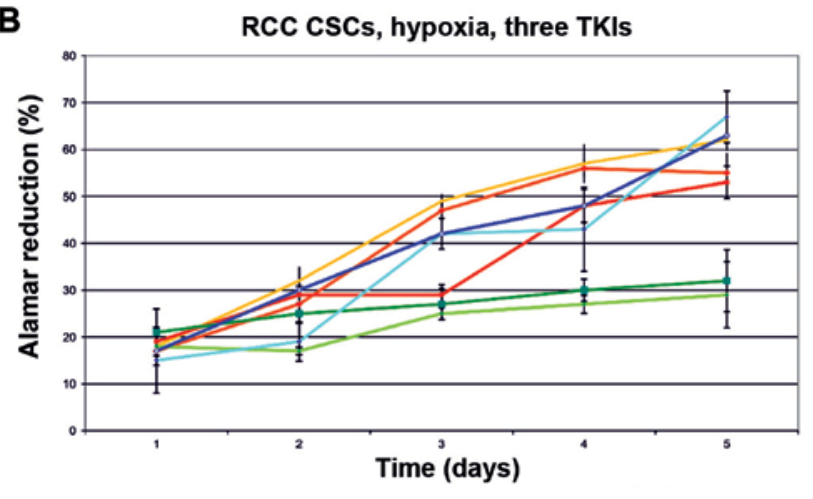

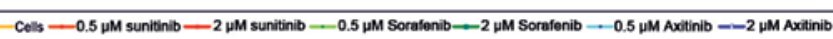

Figure 4. Relative activity of sunitinib, sorafenib and axitinib against renal cell cancer-cancer stem cells (RCC-CSCs) under normoxia (A) and hypoxia (B). TKIs, tyrosine kinase inhibitors.

identified and extensively investigated anti-angiogenic drugs (52); nevertheless, it must be kept in mind that, at a cellular level, it has been shown that TKIs target not only endothelial cells, but also RCC cancer cells, pericytes and renal stromal cells (1). The first pathological condition that was shown to be sunitinib-sensitive was acute myelogenous leukemia (AML), in which sunitinib markedly inhibited cellular proliferation, including AML-stem cell proliferation, in a dose-dependent manner with an $\mathrm{IC}_{50}$ of $10-50 \mathrm{nM}(53,54)$. In this study, we report the activity of TKIs against RCC-CSCs, which has not been confirmed previously.

It is known that the anti-proliferative activity is dependent on the presence of constitutively active receptor tyrosine kinase (RTK) targets. Sunitinib binds 73 kinases in addition to its main target, VEGFR-2, while sorafenib binds 40 additional kinases. However, axitinib is the most selective, with 
A

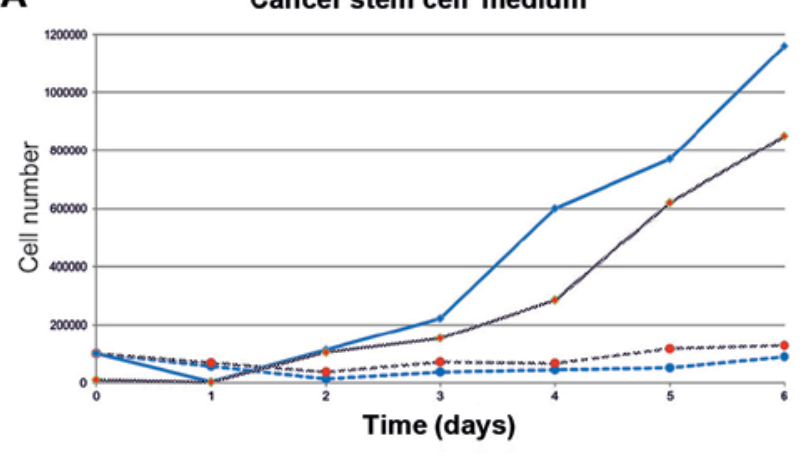

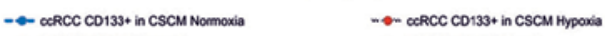
- 7890 in cscun nomoxia
B

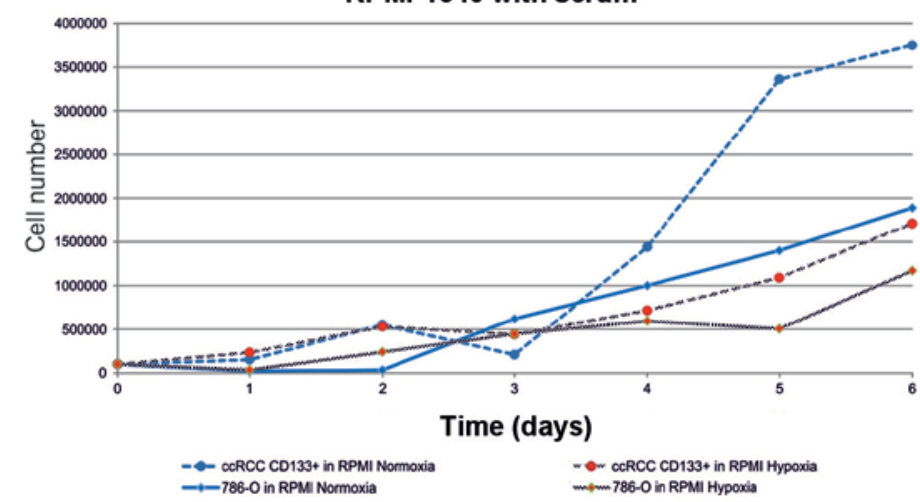

Figure 5. Proliferation of renal cell cancer-cancer stem cells and renal cancer 786-0 cells under hypoxia and normoxia under stem cell-promoting (A) and differentiating (B) conditions.
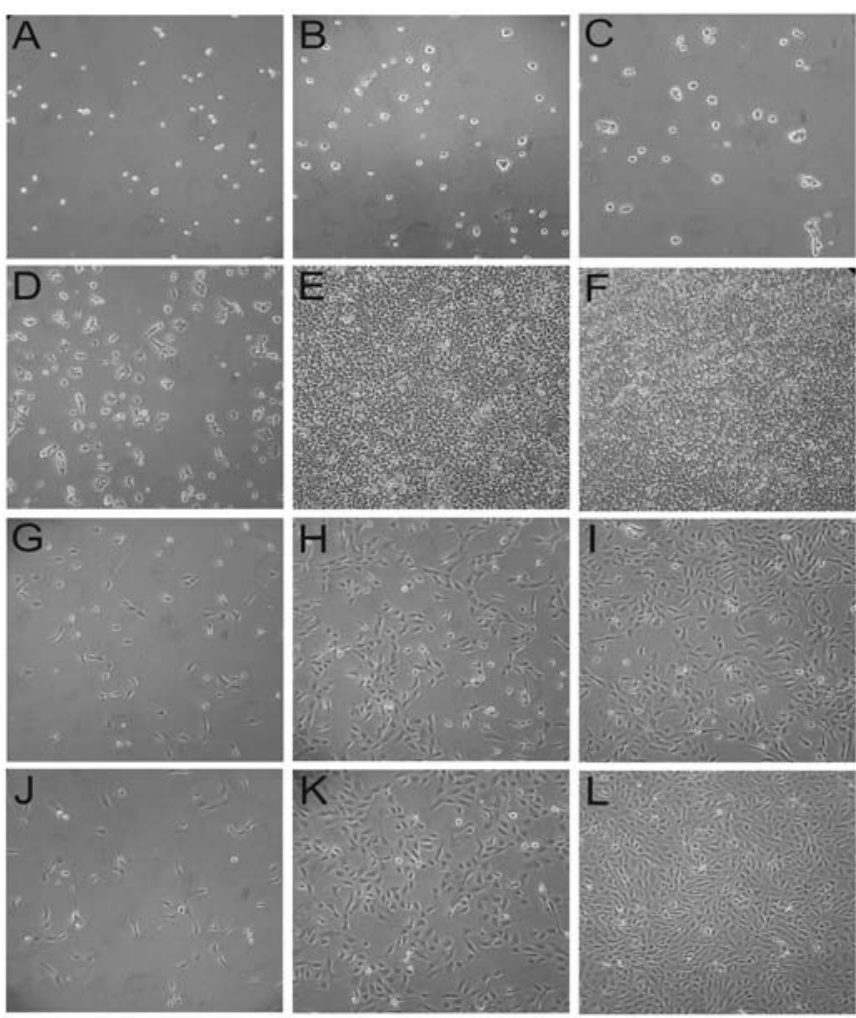

Figure 6. Proliferation of renal cell cancer-cancer stem cells (RCC-CSCs) and renal cancer cells under stem cell-promoting and differentiating conditions. RCC-CSCs in cancer stem cell medium after 24 (A), 48 (B), and $96 \mathrm{~h}$ (C) of culture. ccRCC CSC differentiation in RPMI-1640/FBS after 24 (D), 48 (E) and $96 \mathrm{~h}$ (F). 786-O cells in cancer stem cell medium after $24(\mathrm{G}), 48(\mathrm{H})$ and $96 \mathrm{~h}(\mathrm{I})$ of culture; 786-O cells in RPMI-1640/FBS after $24(\mathrm{~J}), 48(\mathrm{~K})$ and $96 \mathrm{~h}(\mathrm{~L})$ of culture.

a limited number of targets (55). The activity of sorafenib in our CSC research appeared to be the highest under the harsh conditions of hypoxia. In addition, the high activity against a generally drug-resistant target (CSCs) remains in accordance with a wide spectrum of kinases that are inhibited by sorafenib, and therefore, a wider panel of anti-stem cell proliferation inhibitors and hypoxia induced genes. It is known that sorafenib targets kinases in addition to VEGFR, which are in order of increasing $\mathrm{IC}_{50}$ value: platelet-derived growth
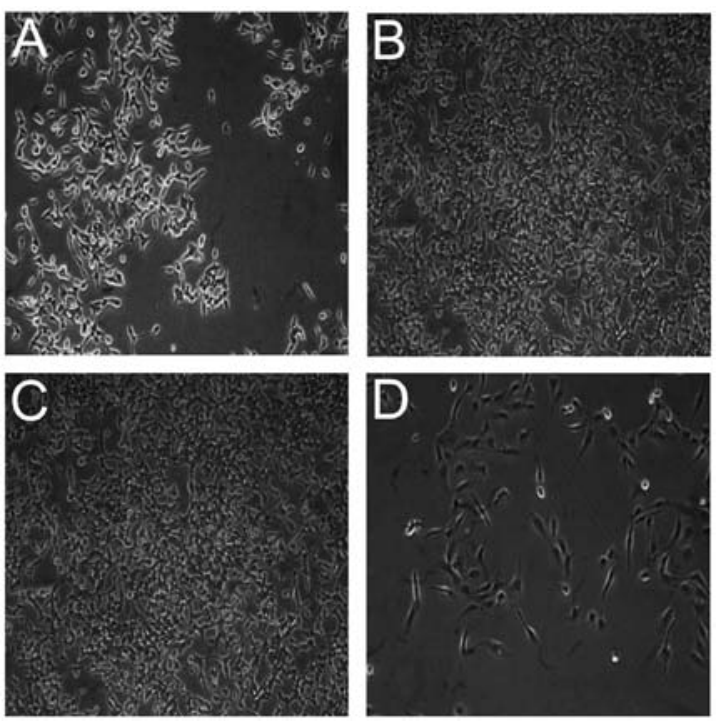

Figure 7. Morphology of renal cell cancer-cancer stem cells in ECM-reach culture (A) and under no-ECM coating (B) conditions in normoxia (B and C) and hypoxia (D).

factor receptor $\alpha(\operatorname{PDGFR} \alpha) \rightarrow$ discoidin domain receptor tyrosine kinase $2($ DDR2) $\rightarrow$ rearranged during transfection $($ RET) $\rightarrow$ homeodomain-interacting protein kinase 4 (HIPK4) $\rightarrow$ fms-like tyrosine kinase 4 (FLT4, also known as VEGFR3) $\rightarrow$ FLT1 (also known as VEGFR1) $\rightarrow$ kinase insert domain receptor (KDR, also known as VEGFR2) $\rightarrow$ PDGFR $\beta \rightarrow$ RAF1 and FLT3. The $\mathrm{IC}_{50}$ values of sorafenib for these 10 kinases were no greater than 100 -fold those against its top target. At the same time, sunitinib had 30 kinase targets within similar $\mathrm{IC}_{50}$ ranges, suggesting that sorafenib might be more selective against the VEGFR family (Fig. 4) (56).

In vitro, sunitinib inhibits the growth of cancer cell lines driven by VEGF, SCF and PDGF, and also induces apoptosis of vein endothelial cells (57); however, a full understanding of the targets and mechanism of action of sunitinib, as well as the other TKIs in ccRCC treatment, remains incomplete. To complement this activity data, we showed direct inhibition of the ccRCC-CSC growth in a dose-dependent manner (Figs. 1, 2 and 4). At the same time, axitinib that was 
HKCSC with sunitinib growth curve $24 \mathrm{~h}$

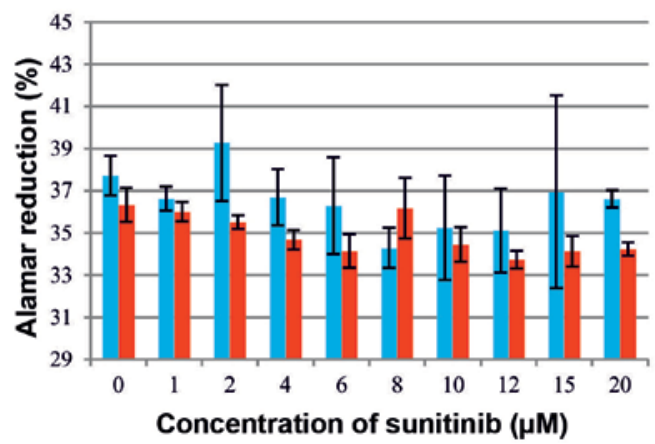

HKCSC with sunitinib growth curve

$72 \mathrm{~h}$

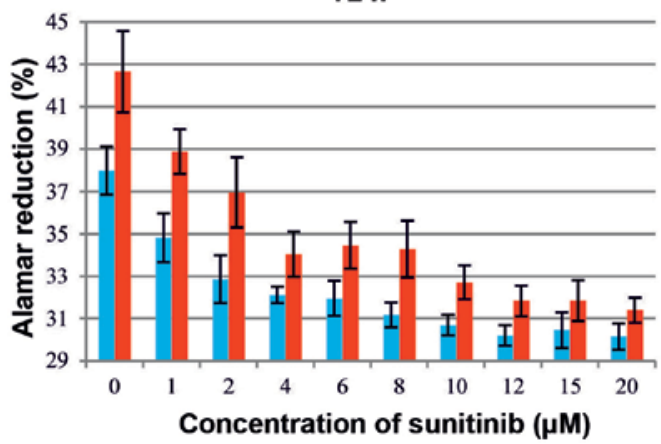

Figure 8. Proliferation of renal cell cancer-cancer stem cells (HKCSCs) under hypoxia (red) and normoxia (blue) after 24 (A) and $72 \mathrm{~h}$ (B) of sunitinib treatment.

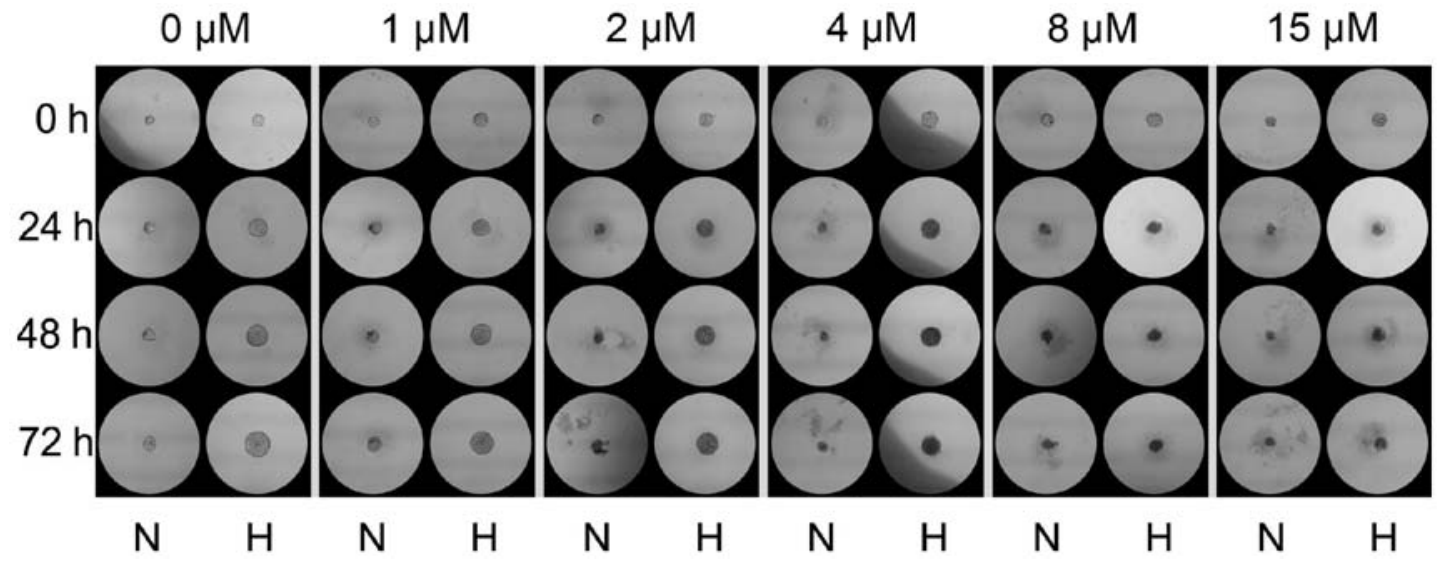

Figure 9. Inhibition of 3D renal cell cancer-cancer stem cell spheroid formation under hypoxia (H) and normoxia (N) after 24, 48 and $72 \mathrm{~h}$ of sunitinib treatment.

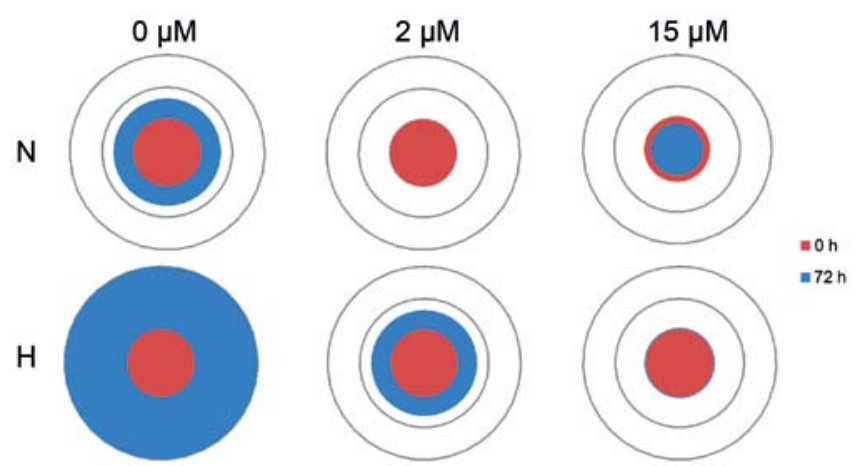

Figure 10. Mean size of spheroids formed by renal cell cancer-cancer stem cells under normoxia (blue) or hypoxia (red) in comparison to maximal spheroid size developed (grey line) - developed without and under sunitinib treatment $(0,2$ and $15 \mu \mathrm{M})$.

found to have lower activity against RCC-CSCs (Fig. 3) was shown to have an 8 - to 25 -fold higher $\mathrm{IC}_{50}$ against PDGFR- $\beta$, KIT, and PDGFR- $\alpha$ (1.6-2.0 nmol/l) and a significantly lower activity against FGFR-1, Flt-3 and RET (1 $\mu \mathrm{mol} / \mathrm{l})$ (29). This specificity may be contradictory to the phenotype of RCC-CSCs and their proliferation triggering pathways.
Our results with regard to the direct activity of TKIs against RCC cancer cells are confirmed by other in vitro and animal studies in which sunitinib targeted the tumor cells themselves, since these cells express one or more target RTKs, including the human kidney cancer 786-O cell line which we used as the control (58). In 786-0 cells, the PDGFR $\beta$ is highly constitutively activated and VEGFR-2 expression is upregulated (58); therefore, it is a target of TKIs. Similar gene expression deregulation has been reported in RCC tumors in clinical reports; for example, PDGF $\beta$ and VEGFR-2 were reported to be overexpressed in RCCs, relative to normal renal tissues (11). Therefore, we suggest that the multi-targeted inhibition of tyrosine kinase by sunitinib/sorafenib/axitinib contributes to its anti-proliferative effects against ccRCC-CSCs, and may contribute to its clinical efficacy in RCC (Figs. 4, 8 and 10).

The concentrations that are being described as inhibiting RCC-CSCs (Figs. 2, 3 and 7) are in the range that is found within RCC tumors in patients. For example, the intra-tumoral concentrations of sunitinib in mice and human patients are $10.9 \pm 0.5$ and $9.5 \pm 2.4 \mu \mathrm{mol} / 1$, respectively, whereas the serum measured concentrations are 10-fold lower, and described as $1.0 \pm 0.1$ and $0.3 \pm 0.1 \mu \mathrm{mol} / 1$, respectively (59). The serum concentration of sunitinib was similar to that in other healthy organs, including the skin, where the concentration was measured at a level of 0.1 to $0.4 \mu \mathrm{M}$ (60). The high concentra- 
tion of TKIs in RCC tumors has been investigated, and was determined to result in multiple codependent mechanisms. The TKIs extravasate into the tumor's extracellular matrix (ECM), while the decrease in the tumor interstitial fluid pressure that arises as a result of anti-angiogenesis slows the leakage of TKIs from the tumor, leading to longer TKI retention in the tumor. At the same time, as the blood flow to the tumor decreases in response to anti-angiogenesis, the blood flow out of the tumor may also decrease. In particular, axitinib was shown to slow the drug efflux from tumors (61); as a result, sunitinib inhibits the tumor cell growth at clinically relevant concentrations in vitro, with $\mathrm{IC}_{50}$ values of at least 1.4 to $2.3 \mu \mathrm{M}$ (59). In addition, in RCC cell lines, the anti-proliferative effects of sorafenib are both concentration- and time-dependent, as is the case in our RCC-CSCs. The calculated $\mathrm{IC}_{50}$ of sorafenib was in the range of 7.5-10 $\mu \mathrm{M}$, depending on the RCC cell line, and sorafenib-induced RCC cell apoptosis was reported after 48-72 h of treatment (62).

In terms of the RCC cell targeted activity of TKIs, it was shown that the short-term $(24 \mathrm{~h})$ application of sunitinib in renal cell carcinoma Caki-1 and KTC-26 cell lines induced cell growth inhibition, which was halted in the $M$ and $G_{2}$ phases. The signs of anti-RCC cell toxicity became apparent when the cells were exposed to $10 \mu \mathrm{M}$ of sunitinib; additionally, sorafenib caused a distinct downregulation of the tumor cell number at a dosage of $\geq 5 \mu \mathrm{M}$ (63). However, when RCC cells were exposed to $1 \mu \mathrm{M}$ sunitinib for 8 weeks (equivalent to a 1.3 treatment cycle) cdk1 and cdk2 were overexpressed, p27 was downregulated, and Akt, Rictor, and Raptor were activated (63). It was previously shown that the wild-type pVHL expressing CAKI-1 and 786-0-VHL (VHL-transfected) cells were $\sim 2$-fold more resistant to the anti-proliferative effects of sorafenib $(2.5-20 \mu \mathrm{M})$ under hypoxic conditions, when compared with the mutant pVHL expressing CAKI-2 and 786-0 cells. Such a difference was not reported under normoxia (62). The phenomenon of TKI activity dependence on tumor niche oxygen availability is also true for RCC-CSCs (Figs. 3, 6 and 7). In order to explain this phenomenon in RCCs, the gene expression in the 786-0-VHL cells (wt VHL transfected) vs. the 786-0-neo cells (VHL mutant) were investigated. As many as 40 genes, mostly related to the inhibition of apoptosis (e.g., BAG1bcl2-associated athanogene) and angiogenesis (e.g., PDGF $\beta$ ), were shown to be $>5$-fold overexpressed under hypoxia in the RCC model. These genes, including BAG-1 and PDGF $\beta$, were downregulated $>2$-fold under hypoxia with sorafenib treatment in both cell types. It was finally concluded that

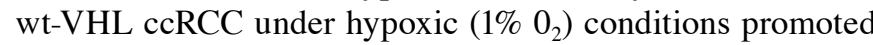
the overexpression of anti-apoptotic and pro-angiogenic genes that attenuated the anti-proliferative effects of sorafenib (62). In our study, hypoxia limited the efficacy of the TKIs in both the 3D model and RCC-CSC proliferation and influenced their morphology, which further confirmed the significant role of oxygen in tumor development (Figs. 7, 8 and 10).

Anti-angiogenic agents generate intratumoral hypoxia, modulating the metastatic process and stimulating cancer stem cells (CSCs) (37). Currently, determining the most effective application of TKIs clinically in RCC treatment is imperative to investigate the mechanisms underlying their efficacy. It remains to be determined whether the in vivo efficacy of compounds such as sunitinib, sorafenib or axitinib can be explained in terms of its inhibition of one (or a combination) of its targets in various tumor cells. As an example of this approach, the primary goal of our study was to describe the action of these TKIs in vitro, but in a clinically relevant model or RCC-CSCs. The findings presented here not only broaden our understanding of the role of hypoxia in RCC-CSC biology, but may have significant clinical implications, since angiogenesis has been a long-standing therapeutic target in ccRCC.

\section{Acknowledgements}

This project was supported by the Foundation for Polish Science Team project TEAM/2010-6/8. Scribendi proofreading service (Scribendi Inc. Chatham, ON, Canada) was covered by A.M.C.

\section{References}

1. Buczek M, Escudier B, Bartnik E, Szczylik C and Czarnecka A: Resistance to tyrosine kinase inhibitors in clear cell renal cell carcinoma: From the patient's bed to molecular mechanisms. Biochim Biophys Acta 1845: 31-41, 2014.

2. Młot B, Szczylik C and Rzepecki P: Seeking new prognostic and predictive factors in patients with metastatic renal cell carcinoma - hypoxia-induced factors. Contemp Oncol (Pozn) 16: 250-253, 2012.

3. Bielecka ZF, Czarnecka AM and Szczylik C: Genomic analysis as the first step toward personalized treatment in renal cell carcinoma. Front Oncol 4: 194, 2014.

4. Porta C, Bellmunt J, Eisen T, Szczylik C and Mulders P: Treating the individual: The need for a patient-focused approach to the management of renal cell carcinoma. Cancer Treat Rev 36: $16-23,2010$.

5. Escudier B, Szczylik C, Porta C and Gore M: Treatment selection in metastatic renal cell carcinoma: Expert consensus. Nat Rev Clin Oncol 9: 327-337, 2012.

6. Ning X, Shu J, Du Y, Ben Q and Li Z: Therapeutic strategies targeting cancer stem cells. Cancer Biol Ther 14: 295-303, 2013.

7. Chow EK: Implication of cancer stem cells in cancer drug development and drug delivery. J Lab Autom 18: 6-11, 2013.

8. Matak D, Szymanski L, Szczylik C, Sledziewski R, Lian F, Bartnik E, Sobocinska A and Czarnecka AM: Biology of renal tumour cancer stem cells applied in medicine. Contemp Oncol (Pozn) 19: A44-A51, 2015.

9. Czarnecka AM and Szczylik C: Renal cell carcinoma cancer stem cells as therapeutic targets. Curr Signal Transduct Ther 8: 203-209, 2013.

10. Roskoski R Jr: Sunitinib: A VEGF and PDGF receptor protein kinase and angiogenesis inhibitor. Biochem Biophys Res Commun 356: 323-328, 2007.

11. Huang D, Ding Y, Li Y, Luo WM, Zhang ZF, Snider J, Vandenbeldt K, Qian CN and Teh BT: Sunitinib acts primarily on tumor endothelium rather than tumor cells to inhibit the growth of renal cell carcinoma. Cancer Res 70: 1053-1062, 2010.

12. Padhye SS, Guin S, Yao HP, Zhou YQ, Zhang R and Wang MH: Sustained expression of the RON receptor tyrosine kinase by pancreatic cancer stem cells as a potential targeting moiety for antibody-directed chemotherapeutics. Mol Pharm 8: 2310-2319, 2011.

13. Diaz R, Nguewa PA, Redrado M, Manrique I and Calvo A: Sunitinib reduces tumor hypoxia and angiogenesis, and radiosensitizes prostate cancer stem-like cells. Prostate 75: 1137-1149, 2015.

14. Varna M, Gapihan G, Feugeas JP, Ratajczak P, Tan S, Ferreira I, Leboeuf C, Setterblad N, Duval A, Verine J, et al: Stem cells increase in numbers in perinecrotic areas in human renal cancer. Clin Cancer Res 21: 916-924, 2015.

15. Adnane L, Trail PA, Taylor I and Wilhelm SM: Sorafenib (BAY 43-9006, Nexavar), a dual-action inhibitor that targets RAF/MEK/ERK pathway in tumor cells and tyrosine kinases VEGFR/PDGFR in tumor vasculature. Methods Enzymol 407: 597-612, 2006. 
16. Xin HW, Ambe CM, Hari DM, Wiegand GW, Miller TC, Chen JQ, Anderson AJ, Ray S, Mullinax JE, Koizumi T, et al Label-retaining liver cancer cells are relatively resistant to sorafenib. Gut 62: 1777-1786, 2013.

17. Chow AK, Ng L, Lam CS, Wong SK, Wan TM, Cheng NS, Yau TC, Poon RT and Pang RW: The enhanced metastatic potential of hepatocellular carcinoma (HCC) cells with sorafenib resistance. PLoS One 8: e78675, 2013.

18. Hashimoto N, Tsunedomi R, Yoshimura K, Watanabe Y, Hazama S and Oka M: Cancer stem-like sphere cells induced from de-differentiated hepatocellular carcinoma-derived cell lines possess the resistance to anti-cancer drugs. BMC Cancer 14 $722,2014$.

19. Yamada T, Abei M, Danjoh I, Shirota R, Yamashita T, Hyodo I and Nakamura Y: Identification of a unique hepatocellular carcinoma line, Li-7, with CD13(+) cancer stem cells hierarchy and population change upon its differentiation during culture and effects of sorafenib. BMC Cancer 15: 260, 2015.

20. Shan J, Shen J, Liu L, Xia F, Xu C, Duan G, Xu Y, Ma Q, Yang Z, Zhang Q, et al: Nanog regulates self-renewal of cancer stem cells through the insulin-like growth factor pathway in human hepatocellular carcinoma. Hepatology 56: 1004-1014, 2012.

21. Galuppo R, Maynard E, Shah M, Daily MF, Chen C, Spear BT and Gedaly R: Synergistic inhibition of HCC and liver cancer stem cell proliferation by targeting RAS/RAF/MAPK and WNT/ $\beta$-catenin pathways. Anticancer Res 34: 1709-1713, 2014.

22. Gedaly R, Galuppo R, Musgrave Y, Angulo P, Hundley J, Shah M, Daily MF, Chen C, Cohen DA, Spear BT, et al: PKI-587 and sorafenib alone and in combination on inhibition of liver cancer stem cell proliferation. J Surg Res 185: 225-230, 2013.

23. Rausch V, Liu L, Kallifatidis G, Baumann B, Mattern J Gladkich J, Wirth T, Schemmer P, Büchler MW, Zöller M, et al: Synergistic activity of sorafenib and sulforaphane abolishes pancreatic cancer stem cell characteristics. Cancer Res 70 5004-5013, 2010.

24. Lee JH, Shim JW, Choi YJ, Heo K and Yang K: The combination of sorafenib and radiation preferentially inhibits breast cancer stem cells by suppressing HIF-1 $\alpha$ expression. Oncol Rep 29: 917-924, 2013.

25. Carra E, Barbieri F, Marubbi D, Pattarozzi A, Favoni RE, Florio T and Daga A: Sorafenib selectively depletes human glioblastoma tumor-initiating cells from primary cultures. Cell Cycle 12: 491-500, 2013.

26. Aldea MD, Petrushev B, Soritau O, Tomuleasa CI, Berindan-Neagoe I, Filip AG, Chereches G, Cenariu M, Craciun L, Tatomir C, et al: Metformin plus sorafenib highly impacts temozolomide resistant glioblastoma stem-like cells. J BUON 19: 502-511, 2014.

27. Chen G, Nicula D, Renko K and Derwahl M: Synergistic anti-proliferative effect of metformin and sorafenib on growth of anaplastic thyroid cancer cells and their stem cells. Oncol Rep 33: 1994-2000, 2015

28. Zhang $\mathrm{K}$ and Waxman DJ: Impact of tumor vascularity on responsiveness to antiangiogenesis in a prostate cancer stem cell-derived tumor model. Mol Cancer Ther 12: 787-798, 2013.

29. Hu-Lowe DD, Zou HY, Grazzini ML, Hallin ME, Wickman GR, Amundson K, Chen JH, Rewolinski DA, Yamazaki S, Wu EY, et al: Nonclinical antiangiogenesis and antitumor activities of axitinib (AG-013736), an oral, potent, and selective inhibitor of vascular endothelial growth factor receptor tyrosine kinases 1,2 , 3. Clin Cancer Res 14: 7272-7283, 2008.

30. Fenton BM and Paoni SF: The addition of AG-013736 to fractionated radiation improves tumor response without functionally normalizing the tumor vasculature. Cancer Res 67: 9921-9928, 2007.

31. Wang F, Mi YJ, Chen XG, Wu XP, Liu Z, Chen SP, Liang YJ, Cheng C, To KK and Fu LW: Axitinib targeted cancer stemlike cells to enhance efficacy of chemotherapeutic drugs via inhibiting the drug transport function of ABCG2. Mol Med 18: 887-898, 2012.

32. Lu L, Saha D, Martuza RL, Rabkin SD and Wakimoto H: Single agent efficacy of the VEGFR kinase inhibitor axitinib in preclinical models of glioblastoma. J Neurooncol 121: 91-100, 2015.

33. McKenzie BA, Zemp FJ, Pisklakova A, Narendran A, McFadden G, Lun X, Kenchappa RS, Kurz EU and Forsyth PA: In vitro screen of a small molecule inhibitor drug library identifies multiple compounds that synergize with oncolytic myxoma virus against human brain tumor-initiating cells. Neuro Oncol 17: 1086-1094, 2015
34. Gomez-Casal R, Bhattacharya C, Ganesh N, Bailey L, Basse P, Gibson M, Epperly M and Levina V: Non-small cell lung cancer cells survived ionizing radiation treatment display cancer stem cell and epithelial-mesenchymal transition phenotypes. Mol Cancer 12: 94, 2013.

35. Conley SJ, Gheordunescu E, Kakarala P, Newman B, Korkaya H, Heath AN, Clouthier SG and Wicha MS: Antiangiogenic agents increase breast cancer stem cells via the generation of tumor hypoxia. Proc Natl Acad Sci USA 109: 2784-2789, 2012.

36. Piao Y, Liang J, Holmes L, Zurita AJ, Henry V, Heymach JV and de Groot JF: Glioblastoma resistance to anti-VEGF therapy is associated with myeloid cell infiltration, stem cell accumulation, and a mesenchymal phenotype. Neuro Oncol 14: 1379-1392, 2012.

37. Chinchar E, Makey KL, Gibson J, Chen F, Cole SA, Megason GC, Vijayakumar S, Miele L and Gu JW: Sunitinib significantly suppresses the proliferation, migration, apoptosis resistance, tumor angiogenesis and growth of triple-negative breast cancers but increases breast cancer stem cells. Vasc Cell 6: 12, 2014

38. Clery JP, Gomez E, Sharma M, Khemani A, Sharma C, Punzalan R, Navel M, Amezcua N, Jani J and Sharma J: Optimal drug concentration screening and evaluation in cancer stem cells $\& 3 \mathrm{D}$ tumor stem cell cultures drug response assays in association with clinical efficacy for pancreatic cancer stem cell. Cancer Res 73: 5545, 2013. doi: 10.1158/1538-7445.AM2013-5545.

39. Sharma J, DiMaggio CM, Taw N, Majdoub M, Liles N, Velazquez G, Amezcua N, Sharma C, and SharmaM: Human liver cancer stem cells as a potential target for novel drug therapy and drug discovery. The American Society for Cell Biology 2009 Annual Meeting Regular Abstracts, no. B48, 2009.

40. Cleary JP, Raman D, Punzalan RR, et al: Targeting cancer stem cells as potential new therapy for pancreatic cancer. Cancer Res 72: 4408, 2012.

41. Sharma CVR, Passarini JD, Majdoub MW, DiMaggio CM, Sobhy OM, Punzalan RR, Sharma MRV, Harris-White ME, Warden MW, Sharma SP and Sharma JP: Human triple-negative breast cancer stem cells utilized for drug discovery therapeutics for triple-negative breast cancer patients Cancer Res 70: 3319, 2010.

42. Passarini J, Cleary JP, Kumar P, Newton T, Sharma M, Sharma C, Panunzalan RR, Gill P, Sharma S, Srivastava R, Shankar S and Sharma JP: Screening potential drug candidates for treatment of glioblastoma patients utilizing an in-vivo mouse/rat model system. Cancer Res 71: 3306, 2011.

43. Ebert T, Bander NH, Finstad CL, Ramsawak RD and Old LJ: Establishment and characterization of human renal cancer and normal kidney cell lines. Cancer Res 50: 5531-5536, 1990.

44. Breslin S and O'Driscoll L: Receptor tyrosine kinase targeting in multicellular spheroids. Methods Mol Biol 1233: 161-168, 2015.

45. Foty R: A simple hanging drop cell culture protocol for generation of 3D spheroids. J Vis Exp 51: 2720, 2011.

46. Schneider CA, Rasband WS and Eliceiri KW: NIH Image to ImageJ: 25 years of image analysis. Nat Methods 9: 671-675, 2012.

47. Abramoff MD, Magalhaes PJ and Ram SJ: Image processing with ImageJ. Biophotonics Int 11: 36-42, 2004.

48. Nakayama GR, Caton MC, Nova MP and Parandoosh Z Assessment of the Alamar Blue assay for cellular growth and viability in vitro. J Immunol Methods 204: 205-208, 1997.

49. Triglia D, Sherard Braa S, Yonan C and Naughton GK: Cytotoxicity testing using neutral red and MTT assays on a three-dimensional human skin substrate. Toxicol In Vitro 5: 573-578, 1991.

50. Vistica DT, Skehan P, Scudiero D, Monks A, Pittman A and Boyd MR: Tetrazolium-based assays for cellular viability: A critical examination of selected parameters affecting formazan production. Cancer Res 51: 2515-2520, 1991.

51. Machesky LM: Lamellipodia and filopodia in metastasis and invasion. FEBS Lett 582: 2102-2111, 2008.

52. Négrier S and Raymond E: Antiangiogenic treatments and mechanisms of action in renal cell carcinoma. Invest New Drugs 30: 1791-1801, 2012

53. O'Farrell AM, Abrams TJ, Yuen HA, Ngai TJ, Louie SG, Yee KW, Wong LM, Hong W, Lee LB, Town A, et al: SU11248 is a novel FLT3 tyrosine kinase inhibitor with potent activity in vitro and in vivo. Blood 101: 3597-3605, 2003.

54. Wiernik PH: FLT3 inhibitors for the treatment of acute myeloid leukemia. Clin Adv Hematol Oncol 8: 429-436, 444, 2010. 
55. Karaman MW, Herrgard S, Treiber DK, Gallant $P$, Atteridge CE Campbell BT, Chan KW, Ciceri P, Davis MI, Edeen PT, et al: A quantitative analysis of kinase inhibitor selectivity. Nat Biotechnol 26: 127-132, 2008.

56. Kitagawa D, Yokota K, Gouda M, Narumi Y, Ohmoto H, Nishiwaki E, Akita K and Kirii Y: Activity-based kinase profiling of approved tyrosine kinase inhibitors. Genes Cells 18: $110-122,2013$

57. Mendel DB, Laird AD, Xin X, Louie SG, Christensen JG, Li G, Schreck RE, Abrams TJ, Ngai TJ, Lee LB, et al: In vivo antitumor activity of SU11248, a novel tyrosine kinase inhibitor targeting vascular endothelial growth factor and platelet-derived growth factor receptors: Determination of a pharmacokinetic/pharmacodynamic relationship. Clin Cancer Res 9: 327-337, 2003.

58. Potapova O, Laird AD, Nannini MA, Barone A, Li G, Moss KG, Cherrington JM and Mendel DB: Contribution of individual targets to the antitumor efficacy of the multitargeted receptor tyrosine kinase inhibitor SU11248. Mol Cancer Ther 5: 1280-1289, 2006.

59. Gotink KJ, Broxterman HJ, Labots M, de Haas RR, Dekker H, Honeywell RJ, Rudek MA, Beerepoot LV, Musters RJ, Jansen G, et al: Lysosomal sequestration of sunitinib: A novel mechanism of drug resistance. Clin Cancer Res 17: 7337-7346, 2011.
60. Gotink KJ, Broxterman HJ, Honeywell RJ, Dekker $\mathrm{H}$, de Haas RR, Miles KM, Adelaiye R, Griffioen AW, Peters GJ, Pili R, et al: Acquired tumor cell resistance to sunitinib causes resistance in a HT-29 human colon cancer xenograft mouse model without affecting sunitinib biodistribution or the tumor microvasculature. Oncoscience 1: 844-853, 2014.

61. Ma J, Chen CS, Blute T and Waxman DJ: Antiangiogenesis enhances intratumoral drug retention. Cancer Res 71: 2675-2685, 2011.

62. Al Hazzouri A, Vaziri SA, Lynch M, Schwartz B, Rini BI, Bukowski R and Ganapathy R: Anti-proliferative effects of sorafenib in clear cell renal cell carcinoma (CCRCC) cell lines: Relationship to von Hippel-Lindau protein (pVHL) expression and hypoxia. J Clin Oncol 24: 4601, 2006.

63. Juengel E, Kim D, Makarević J, Reiter M, Tsaur I, Bartsch G, Haferkamp A and Blaheta RA: Molecular analysis of sunitinib resistant renal cell carcinoma cells after sequential treatment with RAD001 (everolimus) or sorafenib. J Cell Mol Med 19: 430-441, 2015. 